\title{
THE POLISH PLUMBER IN THE WEST MIDLANDS: THEORETICAL AND EMPIRICAL ISSUES
}

\author{
Guglielmo MEARDI \\ Warwick Business School, University of Warwick \\ Gibbet Hill Road, Coventry CV4 7AL, UK; e-mail: guglielmo.meardi@wbs.ac.uk
}

\begin{abstract}
The influx of Polish workers into the UK requires a renewal of migration theories and presents important empirical puzzles. Both problems stem from the specificity of this migration wave, which does not correspond to classical models. The inadequacy of classical migration theories is demonstrated by the inaccuracy of forecasts from before 2004. The 'optimistic' forecasts (e.g. Boeri and Brücker 2001) foresaw an influx many times smaller than the actual one. But the 'pessimistic' forecasts were wrong when expecting a movement towards social benefits (so-called 'social raids'). The paper shows how the influx of Polish workers is different from previous migration waves: it is, at least in the intention, short-term, and includes a high share of young women. In addition, these workers maintain strong contacts and networks with their home country (frequent travel, new communication technologies), often compare living conditions from different European countries, and show an unforeseen willingness to join local trade unions. The issue is therefore if these people qualify for the definition of (classic) 'migrants', or of 'transnational migrants' (Pries 2003) or even of 'cosmopolitans' (Cohen 2004)? In this way they could, for instance, combine Polish, British, and generally European values on work and social customs. The paper combines the Worker Registration Scheme data with early findings from research (interviews, case studies) on Poles in the West Midlands. This region has the largest number of new Polish migrants in the UK ( $17 \%$ of the total), together with numerous 'old' Polish communities. This case is particularly interesting because in this region the share of Poles working through temporary agency employment is the highest (57\%). Experiences of both mobilisation and segregation confirm the ambivalent and dynamic nature of this migration wave.
\end{abstract}

Keywords: migration, transnatonalism, Poland, Great Britain, Europe

\section{INTRODUCTION}

The enlargement of the EU in 2004-07 to the East set in motion a greater transnational mobility, which multiplied the economic and social interactions among people from different nationalities. This has immediate policy implications at EU- (EC 2006) and national levels (e.g. the 'transitory periods', the ex-Bolkenstein directive, the 'Polish plumber' effect in the French referendum on the EU Constitutional Treaty), but also deeper social consequences. Many commentators have seen intra-EU 
migration as a source of potentially disruptive tensions, others as a welcome influx of mobility and flexibility in labor markets.

While a large amount of research has been undertaken on this topical issue, deeper debates on the conceptual and methodological implications for migration studies and for the understanding of the European labor market are still only beginning. This paper will discuss how new approaches, linking migration and labor studies, are made necessary by the novelty of this migration wave. On the one side migration studies still have not elaborated an adequate category for classifying this group of migrants and catching their specificity. The concept, developed in the USA, of 'transnational' migrants (Cohen 2004) grasps many features of the phenomenon, but its application to the specificity of EU citizenship and freedom of movement is still explorative, in spite of some promising attempts (Pries 2003). On the other side, labor studies in Europe have focused on the mobility of capital rather than labor, on the assumption that only the former is the mobile factor benefiting from Europeanization. The rare industrial relations studies on new intra-EU migration have focused on applied or trade union issues only (French and Moehrke 2007; Fitzgerald and Hardy 2007), with little integration into the broader labor market context. Taken alone, these two perspectives have failed to foresee and explain the current events. As an effect, there is currently a large knowledge gap on intra-EU migration, a phenomenon which cannot be easily understood on the grounds of models developed for other migration waves.

The utility of such a 'cross-contamination' of different perspectives (which, if taken alone, seem increasingly inadequate) is then shown through exploratory research on the extreme case of Polish workers in the West Midlands, the region with most immigrants from the new EU Member States. Here we find the highest incidence of new migrants' temporary agency work within the UK, a phenomenon clearly calling for both cultural and labor explanations: as a growing form of employment, it responds at the same time to labor process dynamics of increased exploitation and to social dynamics of a new, ambivalent form of migration.

\section{THE INADEQUACY OF CLASSICAL APPROACHES AND THE NEED FOR CROSS-CONTAMINATION}

There is currently a large knowledge gap on intra-EU migration, a phenomenon which cannot be easily understood on the ground of models developed for other migration waves.

For regulatory but also cultural and political reasons, the movement of workers within the EU is different from classic migrations - to the point that most of the workers involved, staying abroad for less then 12 months, do not even qualify for the demographic definition of migrants. Images such as the 'Ryanair migrant' challenge the classical images of migration, but also the well-established representation of the EU labor market, long seen as an imbalance between capital mobility and labor immobility. In addition, this migration wave is different from previous European migrations (e.g. the Italians after World War II) for its gender composition and the large number of unmarried women (near half of the total), raising debates both on the 
nature of the European gender regime, and on the risks of 'care drain', a sensitive issue in the US but still understudied in the EU.

The novelty of the phenomenon is proven by the inaccuracy of the most authoritative forecasts from before 2004. The 'optimistic' forecasts (e.g. Boeri and Brücker 2001, for the European Commission) not only foresaw an influx many times smaller than the actual one $(680,000$ instead of the expected around 50,000 in the first three years in the UK according to the Worker Registration Scheme ${ }^{1}$ ), but they mistook the trend as well: they expected an immediate decrease after the first year, while the number of workers coming to the UK has kept increasing between 2004 and 2006, and only started declining in the second quarter of 2007, probably for simple demographic reasons (decline in the number of 'potential' migrants). ${ }^{2}$ But the 'pessimistic' forecasts (e.g. Sinn and Ochel 2003, supporting the German decision of closing the borders) were equally wrong when expecting a movement towards social benefits (so-called 'social raids'), while in reality the flux has been nearly entirely for work (even in Sweden where social benefits are available for newcomers, or in the case of workers resident for longer than one year in Britain $^{3}$ ). These forecasts, based on individualistic economic models, have failed to understand the social and cultural determinants of migration.

Another unexpected phenomenon is the apparent propensity of Polish workers in the UK and Ireland to join trade unions and mobilize for the defense of their rights. This contrasts with the frequently held (although already rejectable, on the basis of previous experience in countries such as the USA, UK, Italy) assumption of a difficult relationship between migrants and trade unions. The European reality for a few years has shown that the opposite can be the case: trade unions (even if with some major ambiguities) can be at the forefronts of migrants' defense and organizing, in countries as different as the UK (Avci and McDonald 2000) and Spain and Italy (Watts 1998). But even more it challenges the insiders/outsiders models of labor markets, currently often used to promote labor law deregulation in the EU. While the segmented labor market theory (Piore 1979) holds a number of useful insights on migration, pushing it to an insider/outsider dichotomy raises theoretical and political problems. The ideas of 'outsiders' (in a way similar to the sociological concept of 'underclass' or race) were first developed out of a 'progressive' concern for the conditions of the most vulnerable parts of the population, but have been embraced by the political Right to attack existing

1 The data of the WRS include many workers who have worked in the UK only for a short term and may have returned to their home countries, but do not include self-employed nor informal employment (Home Office 2007).

2 The number of successful applicants was 125,880 in 2004 (May-December), 204,965 in 2005, 227,850 in 2006 and 101,375 in the first half of 2007 (Home Office 2007).

3 There is indeed an increase in registered workers with dependants in the UK: in 2004 only $4.4 \%$ of newly registered workers from the A8 had dependants, but in 2006 the number was already $8.7 \%$. The applications for child benefits from NMS citizens have more than tripled between 2005 and 2006 (from 10,363 to 32,803 , with further increases in 2007). However, the number of National Insurance Numbers allocated for benefit or tax credit purposes is only $2.2 \%$ of the total allocated to NMS citizens, the remaining being for employment purposes, and the number of housing or unemployment benefit applications allowed are extremely low at respectively 803 and 2564 , less than $0.5 \%$ of the total of registered workers (Home Office 2007). 
worker rights. Challenging these models as empirically ungrounded (because migrant and local workers' conditions and aspirations are more similar than opposed) has therefore an important political and theoretical dimension. In particular it would help to overcome muddled debates such as those on so-called 'social dumping', which often blame the poorest workers without identifying the specific social processes in place. There are indeed aspects of the migration phenomenon which remind of social dumping in the sense of employers' (rather than employees') intentional strategy of pressure on local labor conditions. A Home Office report on the employers' use of migrant labor, besides praising migrants for their prodigious contribution to the British economy, reported among the many employers' tributes to migrants the following: "...the more favorable work ethic of migrant workers had the effect of encouraging domestic workers to work harder" (Dench et al. 2006: 13). While this may sound as a patent admission of social dumping, the subjective side of migration is missing in all social dumping talks: migrants' hopes and strategies, which may have nothing to do with 'social dumping'.

Integration between industrial relations (including the study of associations, of conflict, and the ethnography of the workplace) and sociological migration studies (including cultural, social and economic sides) is particularly useful to fill this knowledge gap. Industrial relations studies can contribute through their critique of economic models of the labor market (Kaufman 2007), which currently dominates in the perception of the migrant as "closest living embodiment of homo economicus that rational, self-seeking, amoral agent that propels economic models of human behaviour" (McGovern 2007: 218). Specifically, industrial relations' focus not only on state regulations, but also on employers' strategies and on associations (trade unions, employer associations) adds a dimension migration studies have largely neglected by focusing on the individual and/or on families. Through the study of conflict, mobilization and resistance industrial relations avoid the dichotomy between structural and subjective models that exist in migration studies (e.g. all is due either to capitalist interests, or to migrant preferences.) As McGovern (2007) argues, it combines the strengths of institutional economists' focus on demand (the employers) with the sociologists' interest in supply (the workers). Given that work is the main concern of migrants, and that migration is such a big preoccupation for workers, the reciprocal relative ignorance between industrial relations and migration studies is rather striking.

In the EU enlargement, trade unions and employer associations have had an important role in shaping the migration patterns (e.g. Meardi 2002; Bohle and Husz 2005; Gajewska 2006). Relevant is also the patrimony of studies on self-organization of women in trade unions (e.g. Colgan and Ledwith 2002), a phenomenon in many ways similar to that of the current Polish self-organization in British trade unions. In addition, through the study of conflict, mobilization and resistance, industrial relations avoids the dichotomy between structural and subjective models that exists in migration studies (e.g. all is due either to capitalist interests, or to migrant preferences.)

On the other side, the expertise of migration studies, cultural studies and gender studies is a necessary contribution to the understanding of labor market processes of socialization, segregation and discrimination, as industrial relations have been for long

Review of Sociology 13 (2007) 
gender- and ethnicity-blind, as still seen in the mistaken expectations that migrants would not join trade unions. The recent emerging industrial relations studies of migration have provided good examples of innovative qualitative research (e.g. Milkman 2006; Waldinger and Lichter 2003). The neglected role labor market institution has been proven to be important by Erne's (2008) study of the role of 'corporatism' in explaining the more open Swiss labor market in comparison to the German, which would not be explained by cultural or political factors. More generally, the large scale of migration from the new Member States to the UK involves a major shift in the power balance of employment relations, as exemplified by the Bank of England's governor's declaration in August 2007 that immigration is limiting wage growth, and by the Polish government's efforts to retain workers. Such power dynamics require specific industrial relations interpretative tools, such as the 'exit and voice' concepts (Hirschman 1970).

There are some important questions raised by the new wave of intra-EU migration. While different, they can be covered by the same, broad research question: are the workers moving from the new to the old Member States 'migrants' - that is marginalized foreigners in the way described by Sayad (1999) in the case of Algerians in France, who are neither in France nor in Algeria -, or rather new 'EU-cosmopolitans', combining experiences and networks in more than one country, in the way suggested by Cohen (2004)? Within Europe, this question is parallel to that raised by Habermas a decade ago: will the increased interactions between Eastern and Western Europeans (especially in the workplace) lead to social and political mobilization and exclusion that contribute to foster dividing premises of segregation, marginalization and exclusion, or common shared grounds of a transnational and European citizenship (Habermas 1996: 506)? This question has two corollaries. First, are we seeing a new divide between western and eastern European workers (Meardi 2000), or the emergence of some sort of EU-citizenship with potentials for new, cross-border forms of socialization, mobilization and communication? Second, are these migrants clearly different from extra-EU migrants, or do hidden factors (both formal and informal) perpetuate their discrimination/segregation in spite of the EU principles of free mobility?

The next section will discuss some of these questions through specific empirical issues, specifically calling for joint sociological and industrial relations explanations.

\section{EMERGING EMPIRICAL ISSUES}

\section{A) The Effect of 'Open' Borders}

The early experience of 2004-06, as assessed by the European Commission (2006), shows that the 'transitory periods' selectively applied by some countries have had a strong impact on distorting migration flows, notably replacing Germany and Austria with the British isles as preferred destination countries. In the EC's eyes, it also appears that 'opening' the borders to the new Member States' workers is only beneficial. 
On one side, the transition periods introduced in some countries such as Germany generate illegal employment and pseudo self-employment in the form of service provision. As these forms of employment are outside the reach of trade union organization, in the long term this reinforces the barriers between unions and immigrants, who come to perceive the local unions as hostile. When the media (e.g. Gazeta Wyborcza) in the spring of 2007 revealed the extreme exploitation of Polish migrants in the factories of the largest German meat-packing company, Tönnies, the striking thing was not the exploitation itself ( $€ 3.5 /$ hour pay, 84-hour working week), as such can be probably found in extreme cases in all countries. It was rather that this large company had no union at all, and that it did not deny the facts and did not see anything wrong in it, as these were not its own employees, only the employees of a Polish contractor. It was only in September 2007 that German inspectors and trade unions managed to sue Tönnies, after elaborating a particularly complicated argument on the 'fictitious' nature of the service contracts with Polish providers.

On the other side, a country like the UK has seen extensive complementary migration, leading to increased growth, tax revenue, pension funding, inflation controls. The Bank of England, employers and government are particularly satisfied, and no particular social problems have arisen (unemployment is growing the least where immigration is strongest).

This experience has contravened another forecast by Boeri and Brücker, after that of limited migration flows: that of a "race to the top" among countries in restrictive regulations (Boeri and Brücker 2005). In 2006, the majority of EU countries have followed the British example by lifting the restrictions (Portugal, Spain, Italy, Finland, and Greece) or at least eased them (Belgium, Denmark, France, Luxembourg, and the Netherlands). However, little is known about the link between restriction and integration patterns. Even in the UK popular fears are high, as implicitly admitted by the government when closing the borders to Romanians and Bulgarians, who are restricted to agriculture and self-employment.

\section{B) The Gender Dimension}

The large number of young women involved (nearly $50 \%$ of the total) and their strong representation in sectors such as health and hospitality (including homes for the elderly) raises the question of a possible 'European care chain', even if it is clear that most of the personal care sector involves women from outside the EU. One issue for research includes to what extent women in the new Member States are being replaced by immigrants from further East (e.g. Ukraine) in such a 'care chain', and with what consequences. More broadly, the expansion of the sector and its tight connection with immigration raises issues on working conditions in these sectors, characterized by low visibility, difficult social control and personal power relations. It is already known how deskilling and exploitation of migrants follow gender-specific forms (Kofman et al. 2000) and this is confirmed in the case of the Poles (Currie 2007). There are implications not only for career opportunities but also for mobilization. There are signs 
that the mobilization of domestic workers and similar is possible (Schwenken 2005), yet its forms and conditions are still to be identified.

In addition, there is a broader issue on the gender identities and cultures of migrants, as researched by the seminal work by Passerini, Lyon, Capussotti and Laliotou (2007) on Hungarian and Bulgarian women migrants. Gender arrangements are in some regards different in the new and old Member States, as a legacy of full female employment under communism and traditional values in some countries such as Poland. It may be expected that through migration these different cultures get in contact with potential for change, e.g. when Polish women return to their home country. Any evidence of improved equality expectations by returning migrants would support the hypothesis of a potential European space which workers can use to their advantage comparing conditions and upgrading their expectations - the opposite of what the 'social dumping' scenario suggests, and something similar to what multinational companies do on the opposite side.

A sub-question which deserves analysis relates to the specific but telling case of homosexuals, where the gap in treatment is even higher. It is probably impossible to produce quantitative estimates, but the phenomenon of homosexual professionals fleeing Poland seems an extreme occurrence of employees 'voting with their feet' when confronted by hostile systems. Emerging phenomena require investigation, and specifically interpretative research.

\section{C) The Role of Temporary Work Agencies}

The issue of temporary agency work has political (the proposed EU directive on Temporary Agency Work, on which interestingly the UK and Poland are allied in opposing equal rights for agency workers) and symbolic implications. 37\% of registered A8 migrant workers work in "Administration, Business and Management" (Home Office 2007), but this denomination includes all agency workers regardless of the actual job performed. The data on jobs confirm that only a tiny minority is actually in management or professional business jobs (less than 1\%). Moreover, the share of workers in this 'ABM' sector is constantly increasing: it is not a temporary phenomenon.

Does the fact that about a third of workers from the new Member States in the UK receive their first job through agencies stem from choice (flexibility, short-term commitment, cosmopolitanism) or rather from fate (new form of labor market segregation)? In some sectors, especially local public services but also food industry and manufacturing (media reported of thousands of underpaid agency workers at each of the large companies such as BMW, Coca Cola, Corus), trade unions point at an 'apartheid' of migrant workers, through their segregation in agency employment, and early evidence shows that some migrants perceive agency work (with the reduced rights and pay it entails) as a form of discrimination. Do employers pursue a strategy of segregation by perpetuating a discriminatory stereotype of immigrants as people for whom responsibility should be left to agencies? Temporary Work Agencies may 
emerge as both a segregating institution, and as a contested terrain for social mobilization around the issue of migration.

\section{D) Mobilisation between Exit and Voice}

Trade unions have increasingly focused on groups outside their core constituencies. This has followed "contested" as well as "invited" patterns, and resulted in "autonomous" organizing (separate organization or special structures) or "mainstreaming" (Colgan and Ledwith 2002). The former strategies (e.g. feminist initiatives in Italy in the 1970 s, or class, gender and sexual orientation groups in the UK in the 1990s) necessarily call into question the meaning of 'class unity' and cause reactions which may be mediated later. Such strategies are potentially important for migrants, both in improving the respect of their rights, and offering them opportunities for 'active' organizing and self-representation. The case of the Poles in the UK is innovative on two points. First, the role of cross-border linkages (co-operation between Trade Union Congress and Solidarność) raises the issue of a possible EU public space usable by workers (does such co-operation increase the assertiveness of trade unions in Poland?). Second, the experiences of special Polish-language union sections (the first in Southampton) are an interesting case of community unionism but raise particularly deep questions on class unity, given the role of language as a barrier and the potential for conflicting interests between Poles and locals. There are also the side-questions of the situation of the other EU migrants who do not have the "critical mass' for separate organizing, and of the relations with other, older ethnic minorities.

Within the Polish community, there is also the interesting theoretical issue of the class-ethnicity intersection on employment issues: the old Polish migrants (wave of 1945) being culturally distant from the current one, but co-operating on trade union initiatives.

An additional implication is the effect of migration for mobilization in the country of origin. The link between emigration and mobilization can be conceptualized through the link between "exit" and "voice" in the labor market, as two shifting and mutually enforcing responses to dissatisfaction (Hirschman 1970, 1982).

'Voice' has been weak in post-communist Europe (Meardi 2007). With trade union density and collective bargaining figures very low, workers are left to react to problems at work through 'exit', that is — in Hirschman's dichotomy - individual, market-logic options. There are many forms of 'exit' among Central Eastern European workforces, including informal economy, exit from the labor market, populism, abstention, riots, organizational misbehavior, turn-over (Greskovits, 1998). It is migration which has peaked most visibly following EU accession, in spite of improved economic conditions in the NMS. Seen from the perspective of the countries of origin, migration to Western Europe is more important than for the host countries. In the period up to June 2007, 2.5 per cent of active Poles, 2.4 per cent of active Slovaks, 3.1 per cent of active Latvians and 4 per cent of active Lithuanians had registered for work in the UK only (Home Office 2007). Numbers are much lower for the other NMS. The total share of workers who have chosen to 'exit' their countries, at least temporarily, 
after 2004 may be over 10 per cent in the case of the Baltic States and only slightly less in that of Poland and Slovakia. This contrasts with the old Member States, where mobility since the creation of the European Economic Community only affected less than 2 per cent of the workforce.

Such macroscopic exit affects the balance of power in employment relations in the home countries. Both real and potential worker mobility (the right to legal employment in other EU states) after 2004 affects employers less than capital mobility affects employees, as capital remains inherently more mobile than labor. Still, labor shortages are complained of in all NMS, and employer organizations are requesting the easing of migration barriers to workers from their eastern neighbors (Belarus, Russia and Ukraine). The exit threat also forces employers and governments to make concessions they had been unwilling to make before. Wages have been increasing fast since 2004, even if less than productivity and therefore without damaging the competitiveness of these countries: between 2000 and 2006, by 50.6 per cent in Poland, 59.3 per cent in Lithuania, 60.4 per cent in the Czech Republic, 88.9 per cent in Slovakia, 97.8 per cent in Hungary, 100.4 per cent in Estonia and 118.3 per cent in Latvia, as against 26.3 per cent in the Euro area (Eurostat data). However, inflation is marginally higher, and productivity increase much higher in the NMS. This means that actually there is much more wage moderation in the NMS than in Western Europe (Van Gyes et al. 2007). Interestingly, these figures are roughly inversely correlated to collective bargaining coverage (higher in Poland and Slovakia than in the Baltic countries), and wage drift (the difference between actual pay and collectively agreed pay) is greater than in Western Europe. This means that formal industrial relations are not the driving force behind them.

Wage increases are granted not because of union power, but because of exit threats: not surprisingly, they are most generous in sectors such as construction and transport, where employees are most mobile. National and regional governments have also needed to take measures against emigration. Apart from easing immigration from eastern neighbors, they have proposed a number of disparate incentives and policies to 'bring people back'. For instance, the Polish government promised graduates a two-year exemption from social contributions and 20,000-PLN (about 5,000 Euro) grants to set up companies.

Such massive 'exit' may in turn promote 'voice', as voice becomes more attractive when exit opportunities become more 'sticky'. In the current situation, the attractiveness of migration seems bound to decline (in spite of a likely wave at the end of the German and Austrian transitory periods), as suggested by the declining 2007 WRS data: the wage gap between East and West is narrowing, and migrants are discovering, with time, the discrimination and segregation barriers as well as the extra costs they face in the host countries. The recent many examples of worker resurgent assertiveness across the new Member States suggests that such a shift from exit to voice might be starting (Meardi 2007). 


\section{THE WEST MIDLANDS CASE}

This section combines the Worker Registration Scheme data (Home Office 2007) with early findings from research (interviews, case study) on Poles in the West Midlands. The Midlands (East and West) region in 2006 had accumulated the largest number of new Polish migrants in the UK (17\% of the total), having overtaken London and the South East. This combines in the Birmingham area with a considerable 'old' Polish community, the World War II. veterans who preferred England to communist Poland in 1945. This case is particularly interesting because in this region the share of Poles working through temporary agency employment is the highest (57\%, against a national average of $37 \%$ ). The issue of temporary agency work has political (the proposed EU directive on Temporary Agency Work) and symbolic implications: does it stem from choice (flexibility, short-term commitment, cosmopolitanism) or rather from fate (new form of labor market segregation)? Finally, the Midlands has also a relatively high share of new Member States' migrants working in manufacturing (8.5\% against a national average of $7 \%$, but the West Midlands are much more industrialized than the East), the most unionized sector in the country; it is therefore where relations with the unions may be the most developed.

The exploratory research covered the observation of a co-operation project between the Trade Union Councils and the Polish Club in Birmingham, the analysis of a survey conducted within the same project, and ten semi-structured interviews with male and female migrants. ${ }^{4}$

\section{A) Union-Ethnic Co-operation}

The co-operation project between the TUC and the Polish Club has been running in 2006 and 2007, and covers primarily information and advice on basic social and employment rights, with the secondary aims of recruiting and organizing migrants into the unions as well as creating capacities (in terms of organization and expertise) within the Polish Club to pursue such activity autonomously in the future. In practice, it mostly consists in surgeries offered by union experts within the Polish Club one afternoon per week, with translation provided by volunteers of the Polish Club.

The project is interesting first of all for the interaction between cultural/ethnic associations and class-based ones. The Polish Club in Birmingham (officially named Polish Catholic Association) was created by World War II veterans in the post-war period and it has had a mostly cultural and religious function so far (it includes a Church and the most attended event is the Sunday Mass). There is a large generation and cultural gap between that generation of Polish refugees and the current generation of migrants. The old generation's identity was based on staunch anti-communism, and an idealized version of patriotism which is alien to the new generation. The old generation did not even recognize the People's Republic of Poland as a legitimate state

4 This part of the research could not have been conducted without the valuable co-operation of Laura Moczarska who carried out the interviews. 
- while the new generation was born in it and, willy-nilly, it accepted it as a matter of fact. The borders of Poland have also changed so much after 1945 that the two generations may often refer to different homelands: the old one mostly coming from the eastern territories that now belong to the Ukraine or Belarus.

This cultural and generational gap seems to have been bridged, however, by the emergency of the large number of young Polish migrants coming to the Club with requests of help. The Club, lacking the necessary expertise and capacity, turned to the Trade Union Congress which, coincidentally, was keen on starting a project on migrant workers. The project seems to have met the approval of workers and the surgeries enjoy certain popularity. Questions are raised as to the degree to which the secondary aims have been reached, though. Recruitment has been meagre, and the unions doubt about the autonomous capacities developed by the Polish Club. By contrast, the Polish translators already argue to know, by now, all that needs to be said and to be able to answer (even more quickly and effectively) queries without even the presence of the union experts.

Within the project a questionnaire was distributed to the workers benefiting from the surgeries. In 2006, 100 questionnaires were filled in. The results confirm a marginal labor market position: one third was employed by agencies, $30 \%$ did not have a written employment contract (compulsory in the UK) and $22 \%$ did not even have, nor had they requested, a National Insurance Number, and were therefore working illegally.

\section{B) Migrants' Voices: A Suspended Status}

Ten semi-structured interviews on the migration and employment experience were conducted in May 2007 with ten Polish migrants who arrived after 1 May 2004 and were working in the low-pay sector. The sample included five female and five male respondents in order to investigate possible gendered processes. Six interviews were conducted with a specific group, cleaners from one organization, and four at the Birmingham Polish Club within the above-mentioned surgery hours. The interviews had the duration of 50-60 minutes, were conducted in Polish, fully recorded and transcribed, and covered by a confidentiality and anonymity agreement.

The first, clear observation refers to the specific nature of the migration experience of these workers. The migrant status is often 'fluid', unplanned, corresponding to the typology of 'transnational' migrants (Pries 2003). Unlike other groups for which migration is an important, difficult life-choice, for all the interviewees the choice was casual or even unconscious, given the ease of moving between Poland and UK.

I came with a friend and at the beginning it had to be just a 2-month holiday job experience [...] during those 2 months I was without work; I didn't speak English [...] After nearly 2 months we found a job as room attendants in a hotel. Then my friend returned to Poland, I stayed and so I didn't finish university [...]

How long do you plan to stay? 
No idea. But I suspect that I will stay for longer. For a really longer time.

[Female cleaner, 21]

At the beginning it was just... I wouldn't say gambling, but curiosity to see how things are here $[\ldots]$

How long do you plan to stay in this country?

Oh, I don't know how to answer this one... Really difficult to say... I can only say that as long as I have a job here certainly I don't return to Poland.

[Male cleaner, 37]

The first person who came here was my daughter, who signed a contract in Poland to work here. She was in the first year of English at the university and decided that she rather wanted to learn the language here. [...] After 6 months I came to visit her [...] In half a year she had managed to save a good sum, while I was working in Poland for 800zl [Ł140] monthly. I was shocked. [...] This consideration convinced me to stay.

[Female cleaner, 49]

While decisions come accidentally and are varied in their form, the underlying reason is constant and is financial, combined in some cases with interest in the language. But even the financial aims themselves are varied, including raising the money for a flat, for paying back car accident damage, for a pension.

The 'suspended' nature of this migration is confirmed by the very frequent contacts with Poland through telecommunication, usually on a daily basis and with text messages as the most frequent channel. Respondents also use Polish media and information sources regularly, especially the media and satellite TV. In one case, the respondent has Polish satellite TV at home but no British TV.

\section{C) How Migrants Compare Countries}

Some respondents compare the UK with other Western countries they have experience or knowledge of, usually Germany. Maybe surprisingly from a labor right point of view, they all prefer the UK to Germany. Two factors seem to be playing a role: a historical/cultural one (the Polish hostility to Germany) and a recent regulatory one of free access to employment. The resulting opinion is to consider the UK more employee-friendly.

Sure, one can go to Germany, but there it is worse, they treat workers worse. [ Female cleaner, 23]

I am a carpenter and I worked for a long time in Germany. In Germany I have been many times, in various companies and regions and it was varied, things I haven't seen here.

In what sense it was 'varied'?

Apart from all, financially. There was no trust; work was not entirely legal; it wasn't registered in Germany. This was in the 1990s. [...] So far I really praise 
Britain

[Male cleaner, 37]

The praise for Britain is overall, however, very instrumental, as the following quote reveals strikingly.

\author{
...it was an undeclared job so I resigned. [...] I am keen on working legally \\ because I want to stay for 5 years and get the citizenship [...] \\ You said you will apply for citizenship. \\ Yes, because in the future I'd like to go to Australia, and with the British \\ citizenship it's easier. \\ Why leave England? \\ Because here I don't like anything. \\ [Male kitchen aid, 35]
}

\title{
D) The Gender Dimension
}

The interviews reveal quite a striking similarity between female and male migrants: the choice of migrating takes the same form, and women are as proactive as men, including when it is a couple to move. Female respondents are keen on staying on in the labor market, even when they have children or are pregnant. A possible difference is, however, in the age groups: female migrants are either very young or in their 40s (more rarely migrating when with children in school age), while men often migrate in their 30 s. It should be remembered, however, that, according to Home Office data, this migration wave is overwhelmingly very young: $43 \%$ are between 18 and 24, 39\% between 25 and 34 (a further implication of which is that nearly none of these migrants had work experiences under communism). In terms of age, the overall split is $57 \%$ men and $43 \%$ women (Home Office 2007).

The focus on cleaners also reveals that Polish male migrants are ready to cross gendered lines in the labor market, which they would probably not cross in Poland. As a result of this redefinition of gendered roles, which quite typically for migrants puts a higher weight on instrumental than symbolic value of work, interviewees may even perceive gendered labor demand as incongruous.

In hotels, they don't take men. Even if they ask.

[Female cleaner, 23]

\section{E) Temporary Work Agencies}

The UK is the EU country with the largest use of Temporary Work Agencies, and the one with the softest regulations and the least employment rights for Agency workers. It has been reported how in some sectors (especially privatized public services) a very large use of agency workers results in a 'Balkanization' of the labor market separating indigenous and migrant workers. With few exceptions naming 
specific agencies that proved useful, migrants have an overwhelming negative opinion about them.

These agencies are all one big fraud, exploiting people. When there was work, this agency would require 100 people, although it could only employ 20, but with some guarantee of work continuity. And the agency recruited 100, who would compete to work as long as possible, while the agency was only interested in getting the contract as quickly as possible, at the cost of the employees.

[Male cleaner, 34]

They take the transaction fee from everybody. After 6 months you have to renew the contract and they take the fee again. They also take the first week of salary. Even if it is not actually them who found me the job, they just gave me the information. [...] I wanted to leave the agencies; they pay only the minimum wage.

[Male waiter, 29]

These agencies are of no use. [...] Any agency you walk into, they just sit and drink coffee. Maybe they have some state subsidies because otherwise they would not survive. I didn't receive any phone call from any agency for six months.

[Male kitchen aid, 35]

Agencies often take on as many people as they can and pay less than the

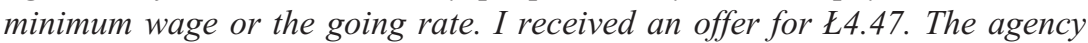
sacked me when they discovered that I was pregnant. They simply told me that since I am pregnant, I cannot work [...]

I know that there is a very good protection for pregnant workers with a permanent contract, but nobody cares about those from agencies such as me. Protection for pregnant agency workers simply does not exist.

[Female warehouse operative, 21]

Respondents detect here some national dividing lines, both in terms of discrimination and segregation.

2 years ago some agencies didn't look positively at Polish job-seekers.

[Male cleaner, 37]

These agencies simply make money on us, for as long as 6 months. They take provisions out of our pay. Not just a transaction fee. I don't have a good opinion about them. The worst is, that firms don't want to employ without the intermediation of agencies. It's a self-enforcing business.

[Male driver, 40]

Such decisively negative views challenge the argument of deregulated agency work as opening opportunities to, and therefore benefiting, migrants (and outsiders as a whole: as the previous quote shows, female migrants suffer even more from agency employment). Although many migrants manage to escape agency work, it is not an 
easy process and employer preference for it combines probably ethnic prejudice with abuse of flexibility and blackmailing. Other research, as well as the media and social organizations, have documented exploitative practices by some agencies, such as illegal pay deductions under the form of accommodation or other social expenses (French and Möhrke 2006). This is clearly a point where more research, covering not just the supply but also the demand of agency work, is required.

\section{F) Mobilization}

The issues emerging from the Polish Club-TUC co-operation can be further examined through migrants' answers. Most migrants have no experience and nearly no interest in trade unionism. According to the TUC survey, $10 \%$ have been trade union members in Poland, and 3\% are members in the UK. Respondents seem to put more hope and trust in Polish organizations rather than in local trade unions.

First of all, the initiative for helping Poles should be taken by the Polish Club.

[Male cleaner, 37]

However, the weak interest in trade unionism should be contextualized and not treated as inherent to migrant or Polish workers. Low unionization is normal for low-pay young employees in temporary employment, whether migrants or not. Some respondents actually express some appreciation for trade unions, while others point at the difficulty in organizing in sectors where the employers are anti-union.

Generally it's always good if there is an institution or a trade union which represents the employees.

[Female cleaner, 49]

There is such a tyrannical management that there is no chance for a trade union. They would sack half of the people.

[Male driver, 40]

There was a trade union but when I arrived it didn't exist anymore. The people who had created it had been sacked, as simple as that. [...] it would be certainly useful; thanks to the union we got a half-hour break.

[Female warehouse operative, 21]

More difficult to understand is the very low interest in unions among the cleaners, given that the workplace is unionized. Here a combination of low attention to diversity by the union, and the relative feeling of privilege enjoyed by the migrants may explain the situation, which might change over time. This is, however, a workplace where some respondents claim to be discriminated against (in comparison to indigenous workers) in the allocation of harder jobs. 


\section{CONCLUDING REMARKS}

The example of the Poles in the West Midlands is symptomatic of the need for integrated (supply and demand, social and cultural) explanations of the current, in many regards innovative migration wave. Migration strategies are at the same time economic-rational and dictated by specific cultural perceptions of opportunities. Mobilization combines unionism with ethnic association. Temporary Agency Work combines employers' segmentation strategies with the extreme flexibility of this group of workers.

Although it is impossible to generalize to a clearly heterogeneous population, the majority of new Polish migrants into the UK correspond more to the idea of 'transnational migrants' than to that of 'classical migrants', as their lives are organized across borders. While the concept of 'transnational migration' had been developed observing the Mexicans in the USA, the enlarged EU, with freedom of movement and low transport costs, is the privileged terrain for such form of worker mobility. It may be even argued that these workers are of an even newer type, as they enjoy EU citizenship. In autumn 2007, the 50,000 Polish Londoners are targeted at the same time by two electoral campaigns: they are visited by Polish party leaders competing for the Polish parliamentary elections, but also by Mr. Livingston, the Mayor of London, targeting them as an important constituency for his re-election and making specific promises to them. As they enjoy the right to vote at both elections, their situation is symbolic of a new form of migration. However, the paper, by focusing on the employment situation, shows how such EU-citizen status does not prevent segregation and exploitation. As the UK government's immigration policy shifts to requiring an English proficiency test to any prospective migrant from outside the EU (such a requirement would be illegally discriminating against EU citizens), workers from the new Member States could become the lowest strata in the British labor market, offering unskilled labor without the language proficiency needed for either developing a career, or claiming rights and mobilizing within the local space. Such a status - particularly 'free' but also often particularly exploited - for so many people is too contradictory not to become a crucial test for EU policies and labor market regulations.

\section{REFERENCES}

Avci, G. and McDonald, C. (2000): Chipping Away at the Fortress: Unions, Immigration and the Transnational Labour Market. International Migration, 38(2): 191-212.

Boeri, T. and Brücker, H. (2001): Eastern Enlargement and EU-Labour Markets: Perceptions, Challenges and Opportunities. IZA Discussion Paper 256.

Boeri, T. and Brücker, H. (2005): Migration, Co-ordination Failures and EU Enlargement. IZA Discussion Paper 1600.

Bohle, D. and Husz, D. (2005): Whose Europe is it? Interest Group Action in Accession Negotiations: The Cases of Competition Policy and Labor Migration. Politique Europeenne, 15: 85-112. 
Cohen, R. (2004): Chinese Cockle-pickers, the Transnational Turn and Everyday Cosmopolitanism: Reflections on the New Global Migrants. Labour, Capital and Society, 37: $130-149$.

Colgan, F. and Ledwith, S. (eds.) (2002): Gender, Trade Unions and Diversity. International Perspectives. London: Routledge.

Currie, S. (2007): De-Skilled and Devalued: The Labour Market Experience of Polish Migrants in the UK Following EU Enlargement. International Journal of Comparative Labour Law and Industrial Relations, 23(1): 83-116.

Dench, S., Hurtsfield, J., Hill, D and Akroyd, K. (2006): Employers' Use of Migrant Labour. Summary Report. London: Home Office.

Erne, R. (2008): European Unions. Labor's Quest for a Transnational Democracy. Ithaca: Cornell University Press.

European Commission (2006): Report on the Functioning of the Transitional Arrangements set out in the 2003 Accession Treaty (period 1 May 2004 - 30 April 2006). Brussels.

Fitzgerald, I. and Hardy, J. (2007): Trade Union Cross Border Collaboration and Polish Migrant Workers in the UK. Paper for the British Universities Industrial Relations Association's Conference. Manchester, September.

French, S. and Möhrke, J. (2007): The Impact of New Arrivals upon the North Staffordshire Labour Market. Keele University.

Gajewska, K. (2006): Restrictions in Labor Free Movement after the EU-Enlargement 2004: Explaining Variation among Countries in the Context of Elites' Strategies towards the Radical Right. Comparative European Politics, 4(4): 379-398.

Greskovits, B. (1998): The Political Economy of Protest and Patience. East European and Latin American Transformations Compared. Budapest: Central European University.

Habermas, J. (1996): Between Facts and Norms: Contributions to a Discourse Theory of Law and Democracy. Cambridge, Mass.: MIT Press.

Hirschman, A. (1970): Exit, Voice, and Loyalty: Responses to Decline in Firms, Organizations, and States. Cambridge, MA: Harvard University Press.

Hirschman, A. (1982): Shifting Involvements. Private Interest and Public Action. Princeton: Princeton University Press.

Home Office (2007): Accession Monitoring Report, May 2004 - June 2007. London.

Kaufman, B. (2007): The Core Principle and Fundamental Theorem of Industrial Relations. International Journal of Comparative Labour Law and Industrial Relations, 23(1): 5-33.

Kofman, E. et al. (2000): Gender and International Migration in Europe: Employment, Welfare and Politics. London: Routledge.

McGovern, P. (2007): Immigration, Labour Markets and Employment Relations: Problems and Perspectives. British Journal of Industrial Relations, 45(2): 217-235.

Meardi, G. (2000): Trade Union Activists, East and West: Comparisons in Multinational Companies. Aldershot: Gower.

Meardi, G. (2002): The Trojan Horse for the Americanization of Europe? Polish Industrial Relations Towards the EU. European Journal of Industrial Relations, 8(1): 77-99.

Meardi, G. (2007): 'More Voice after more Exit? Unstable Industrial Relations in Central Eastern Europe'. Industrial Relations Journal, 38(6): 503-523.

Milkman, R. (2006): L.A. Story: Immigrant Workers and the Future of the U.S. Labor Movement. New York: Russell Sage Foundation.

Passerini, L., Lyon, D., Capussotti, E. and Laliotou, I. (eds.) (2007): Women Migrants from East to West: Gender, Mobility, and Belonging in Contemporary Europe. New York: Berghahn Books. 
Piore, M. (1979): Birds of Passage: Migrant Labor and Industrial Societies. Cambridge: Cambridge University Press.

Pries, L. (2003): The Case of Germany in a Comparative Perspective. Transfer, 9(3): 432-451.

Sayad, A. (1999): La double absence: des illusions de l'émigré aux souffrances de l'immigré. Paris: Seuil.

Schwenken, H. (2005): 'Domestic Slavery'versus 'Women Rights': Political Mobilizations of Migrant Domestic Workers in the European Union. Centre for Comparative Immigration Studies, University of California, Working Paper 116.

Sinn, H-W. and Ochel, W. (2003): Social Union, Convergence and Migration. Journal of Common Market Studies, 41, 5, 869-896.

Van Gyes, G. et al. (2007): Industrial Relations in EU Member States, 2000-2004. Dublin: European Foundation for the Improvement of Living and Working Conditions.

Waldiger, R. and Lichter, M.I. (2003): How the Other Half Works: Immigration and the Social Organization of Labor. Berkeley: University of California Press.

Watts, J. (1998): Italian and Spanish Labour Leaders' Unconventional Immigration Policy and Preferences. South European Society \& Politics, 3(3): 129-149. 